\title{
Fotossensibilização hepatógena em eqüinos pela ingestão de Brachiaria humidicola (Gramineae) no Estado do Pará ${ }^{1}$
}

\author{
José Diomedes Barbosa ${ }^{2 *}$, Carlos Magno C. de Oliveira², Carlos Hubinger Tokarnia ${ }^{3}$ \\ e Paulo Vargas Peixoto ${ }^{3}$
}

\begin{abstract}
Barbosa J.D., Oliveira C.M.C., Tokarnia C.H. \& Peixoto P.V. 2006. [Hepatogenous photosensitization in horses caused by Brachiaria humidicola (Gramineae) in the State of Pará.] Fotossensibilização hepatógena em eqüinos pela ingestão de Brachiaria humidicola (Gramineae) no Estado do Pará. Pesquisa Veterinária Brasileira 26(3):147-153. Escola de Medicina Veterinária, Campus Castanhal, Universidade Federal do Pará, Rua Maximino Porpino 1000, Castanhal, PA 68743080,Brazil.E-mail: diomedes@ufpa.br

Data on the clinical-pathological aspects and on the epidemioloy of a disease in horses, characterized by phototsensitization, which occurs in northeastern of Pará, Brazil, are presented. Of a total of 40 horses examined clinically, post-mortem examination was performed on seven. Due to the characteristic lesions found on the non-pigmented skin, the macroscopic and histological alterations in the liver, and knowing that Brachiaria grasses contain saponins with toxic properties, which cause liver lesions and photosensitization in cattle and sheep, it is concluded that this disease in horses is caused by grassing exclusively Brachiaria humidicola.
\end{abstract}

INDEX TERMS: Poisonous plants, Brachiaria humidicola, plant poisoning, photosensitization, saponins, horses.

RESUMO.- São apresentados os aspectos clínico-patológicos e epidemiológicos de doença, caracterizada por fotossensibilização, que ocorre em eqüinos no nordeste do Estado do Pará. De um total de 40 animais examinados clinicamente, sete foram necropsiados, e tiveram fragmentos de órgãos examinados microscopicamente. Em virtude das lesões características encontradas, sobretudo nas partes despigmentadas da pele, das lesões hepáticas macro e microscópicas, e sabendo-se que as brachiárias, de uma maneira geral, encerram saponinas com propriedades tóxicas, que causam alterações hepáticas e fotossensibilização em bovinos e ovinos, conclui-se, que essa doença fotossensibilizante foi determinada pelo pastoreio de Brachiaria humidicola, alimentação exclusiva dos animais enfermos.

TERMOS DE INDEXAÇ̃̃O: Plantas tóxicas, Brachiaria humidicola,, intoxicação por planta, fotossensibilização, saponinas, eqüinos.

\footnotetext{
${ }^{1}$ Recebido em 4 de fevereiro de 2006.

Aceito para publicação em 8 de fevereiro de 2006.

${ }^{2}$ Escola de Medicina Veterinária, Campus Castanhal, Universidade Federal do Pará, Rua Maximino Porpino 1000, Castanhal, PA 68743-080. "Autor para correspondência: diomedes@ufpa.br

${ }^{3}$ Depto Nutrição Animal e Pastagem, Instituto de Zootecnia, Universidade Federal Rural do Rio de Janeiro, Seropédica, RJ 23890-000, RJ.
}

\section{INTRODUÇÃO}

No Brasil, surtos de fotossensibilização em bovinos e ovinos que pastejam em espécies do gênero Brachiaria, em especial B. decumbens, são muito frequientes (Tokarnia et al. 2000). Em equiinos, todavia, há raros registros desse tipo de ocorrência. Até o momento, sobre o assunto, só encontramos o estudo de Schenk et al. (1991), no qual estes autores avaliaram, experimentalmente, a viabilidade de utilização de Brachiaria humidicola para pastejo de eqüinos no Mato Grosso do Sul. De 24 potrancas colocadas na pastagem com essa gramínea, sete evidenciaram fotossensibilização e uma morreu ao cabo de cinco meses. De significativo, à necropsia desse animal, observaram-se "escaras pelo corpo", mucosas acentuadamente ictéricas, figado aumentado de volume e emagrecimento. O exame microscópico revelou congestão e necrose centrolobular no figado.

No Nordeste ocorrem surtos de fotossensibilização em equiinos, regionalmente conhecidos como sarna, que, de acordo com Riet-Correa (2003), são de natureza primária, isto é, de fotossensibilização direta. Os animais não apresentam outro sinal clínico, além da dermatite e se recuperam rapidamente se forem retirados dos pastos onde ocorre a enfermidade e colocados à sombra. Suspeita-se que a causa desses surtos seja uma planta identificada como Croton hirtus L. Aevit.

Nos últimos sete anos tivemos oportunidade de diagnosticar, na região nordeste do estado do Pará, diversos casos de fotossensibilização em equiinos, com características epidemio-lógicas semelhantes. 
No presente estudo tem-se por objetivo apresentar os dados clínico-patológicos, bem como observações epidemiológicas e alguns parâmetros bioquímicos observados nesses surtos determinados pela ingestão de Brachiaria humidicola.

\section{MATERIAL E MÉTODOS}

Em todas as ocorrências de fotossensibilização observada nos eqüinos no nordeste do Pará, após a colheita do histórico, fazia-se um levantamento sobre a alimentação e inspecionavam-se as pastagens. A seguir, os animais afetados eram submetidos a exame clínico; em um surto foi colhido sangue de eqüinos enfermos ou não para
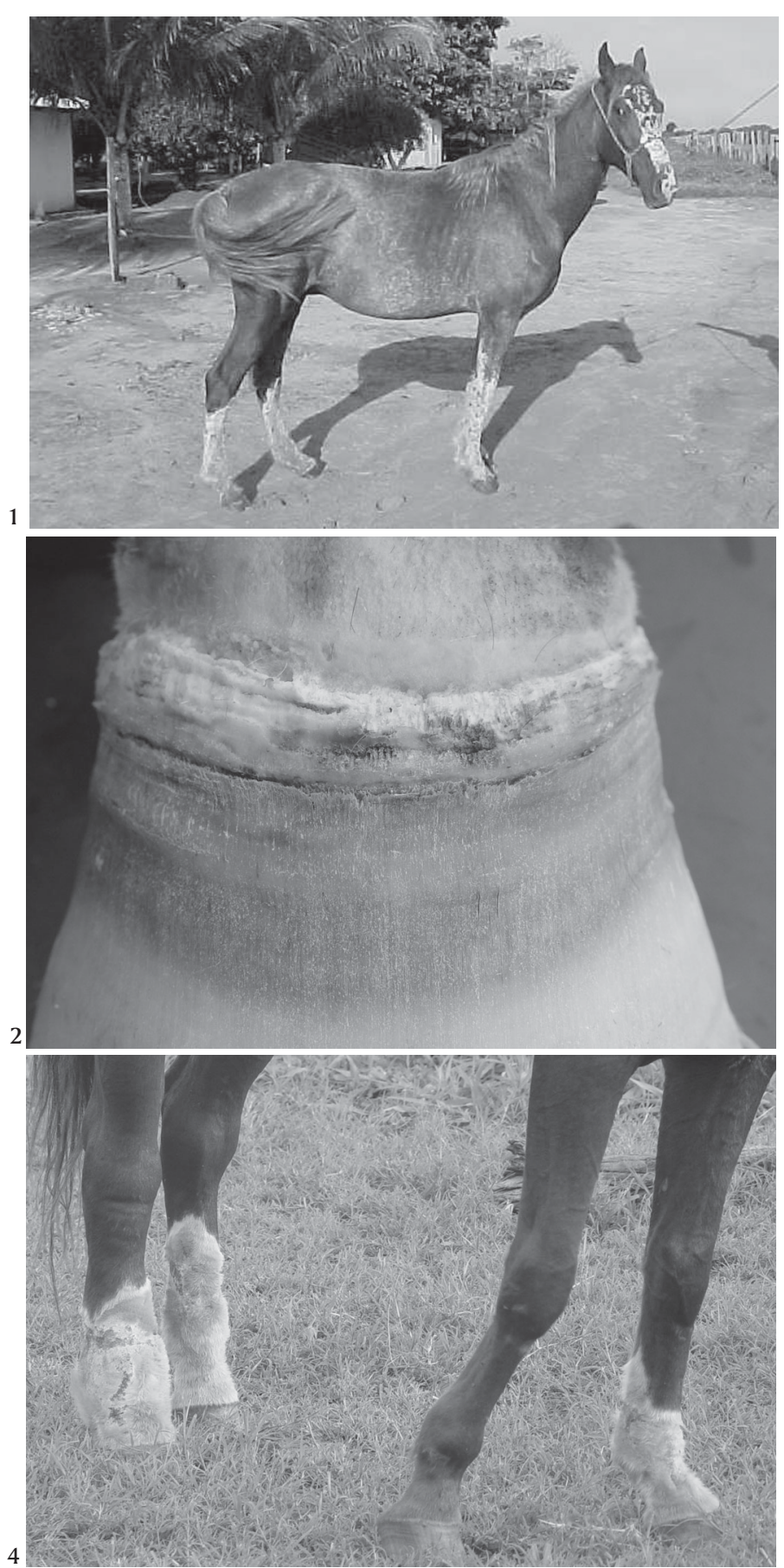

realização de hemograma e determinação de bilirrubina total, direta e indireta e a GGT (glutamil gama transferase). Os valores hematológicos foram avaliados através de contador automático de células (CELM-CC-550) e os níveis de bilirrubina e GGT por meio de espectrofotômetro (BioPlus-Bio-2000).

Sete animais afetados que morreram pela doença ou sacrificados, foram necropsiados, colhendo-se fragmentos dos diversos órgãos em formol a $10 \%$ para realização de exames histopatológicos no Setor de Anatomia Patológica do Convênio "Projeto Sanidade Animal Embrapa/ Universidade Federal Rural do Rio de Janeiro".

\section{RESULTADOS}

\section{Epidemiologia}

Em geral eram registrados casos isolados de fotossensibilização em eqüinos. Apenas em duas propriedades, a doença

Fig.1. Leve fotossensibilização crônica nas áreas despigmentadas dos membros e da face.

Fig.2. Separação (fenda) entre a pele e a camada córnea do casco com congestão da muralha.

Fig.3. Ulceração da borda da pálpebra e da conjuntiva em eqüino com fotossensibilização subaguda.

Fig.4. Espessamento da pele com perda de pêlos nas áreas despigmentadas dos membros.

Fig.5. Ulceração nas áreas despigmentadas da pele da porção inferior dos membros.

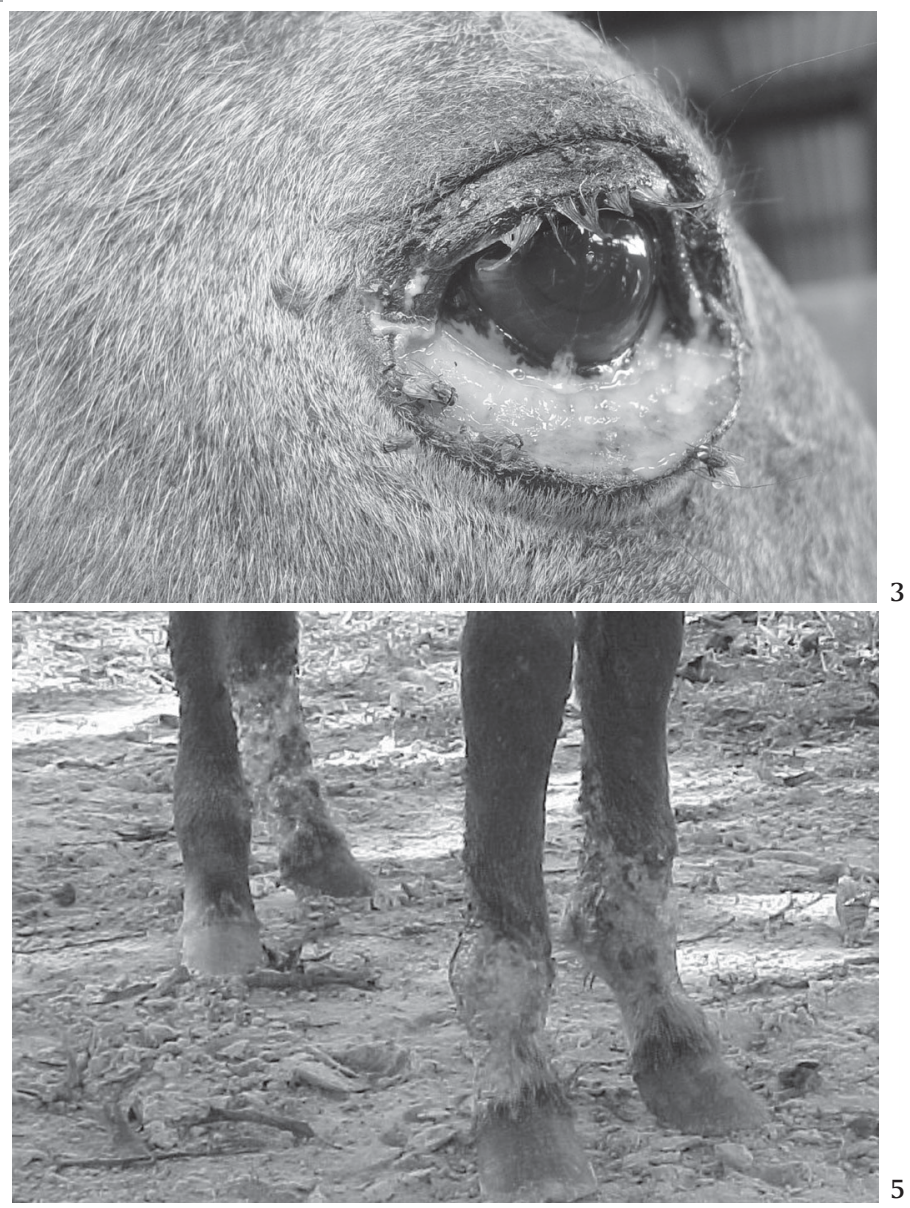




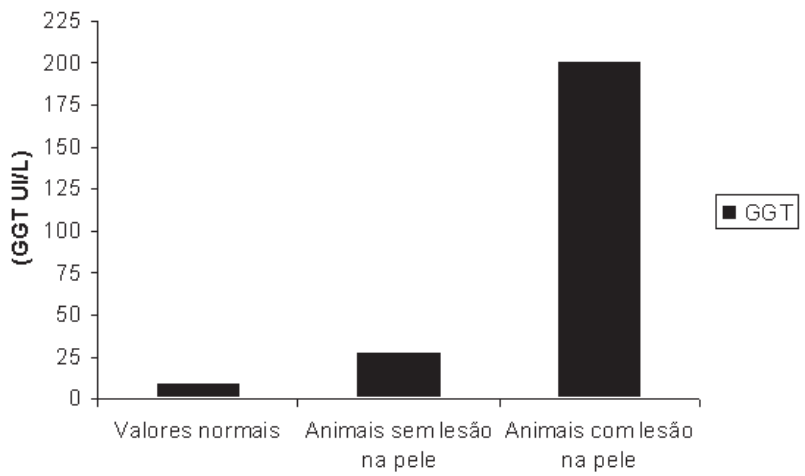

Fig.6. Valores da Gama-glutamiltransferase (GGT) no soro de eqüinos em pastagem de Brachiaria humidicola

\section{Quadro 1. Valores hematológicos e de função hepática de eqüinos em pastagem de Brachiaria humidicola}

\begin{tabular}{lcccc}
\hline \multicolumn{1}{c}{ Parâmetros } & Unidades & $\begin{array}{c}\text { Valores } \\
\text { normais } \\
(\mathrm{n}=13)\end{array}$ & $\begin{array}{c}\text { Animais sem } \\
\text { lesão de pele } \\
(\mathrm{n}=43)\end{array}$ & $\begin{array}{c}\text { Animais com } \\
\text { lesão de pele }\end{array}$ \\
\hline Função hepática & & & & \\
$\quad$ GGT & $\mathrm{UI} / \mathrm{L}$ & $4,3-13,4$ & $26,69 \pm 22,14$ & $199,81 \pm 129,30$ \\
Bilirrubina total & $\mathrm{mg} / \mathrm{dL}$ & $1-2$ & $1,26 \pm 0,39$ & $1,77 \pm 066$ \\
Bilirrubina direta & $\mathrm{mg} / \mathrm{dL}$ & $0-0,4$ & $0,86 \pm 0,33$ & $1,29 \pm 054$ \\
Bilirrubina indireta & $\mathrm{mg} / \mathrm{dL}$ & $0,2-2$ & $0,43 \pm 0,13$ & $0,52 \pm 024$ \\
Valores hematológicos & & & & \\
Hematócrito & $\%$ & $24-44$ & $38,37 \pm 7,05$ & $31,12 \pm 6,20$ \\
Hemácias x & $10^{6}$ & $5,5-9,5$ & $7,08 \pm 1,12$ & $5,93 \pm 1,10$ \\
Hemoglobina & $\mathrm{g} / \%$ & $15,2-18,6$ & $13,04 \pm 2,15$ & $10,70 \pm 2,20$ \\
Leucócitos totais & $\mathrm{x} 10^{3}$ & $6-12$ & $11,28 \pm 1,21$ & $20,97 \pm 7,60$ \\
Neutrofilos & $\%$ & $35-75$ & $38,62 \pm 7,03$ & $56,92 \pm 15,70$ \\
Eosinófilos & $\%$ & $2-12$ & $2,23 \pm 1,88$ & $2,88 \pm 2,00$ \\
Linfócitos & $\%$ & $15-50$ & $54,31 \pm 6,77$ & $36,67 \pm 16,10$ \\
Monócitos & $\%$ & $2-10$ & $2,31 \pm 0,95$ & $2,29 \pm 1,30$ \\
Basófilos & $\%$ & $0-3$ & 0 & 0
\end{tabular}

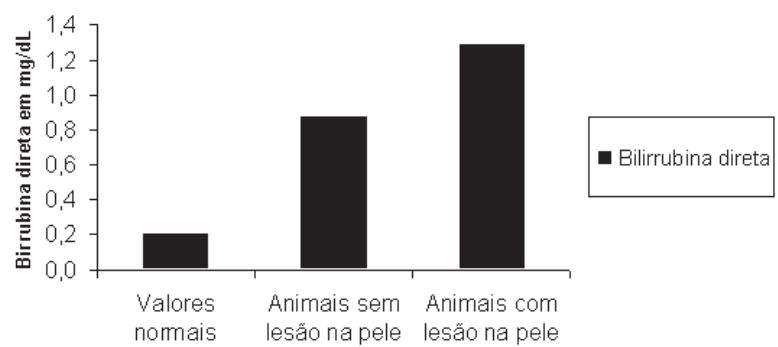

Fig.7. Valores da bilirrubina direta no sangue de eqüinos em pastagem de Brachiaria humidicola.

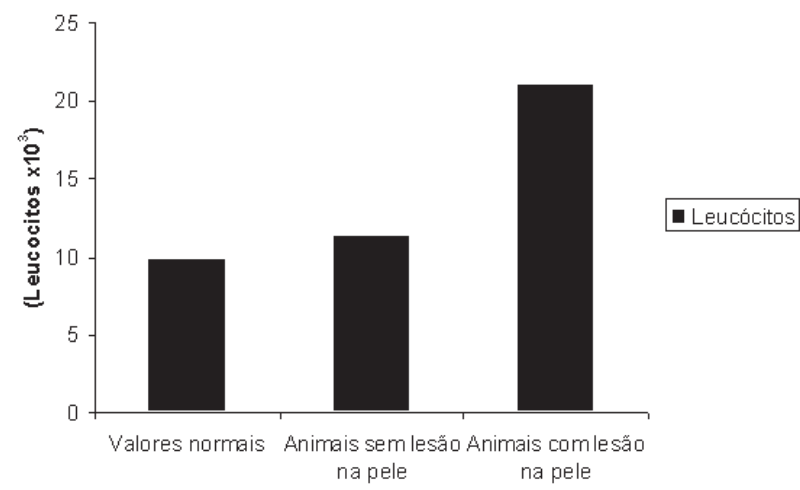

Fig.8. Valores dos leucócitos no sangue de equïnos em pastagem de Brachiaria humidicola.

ocorreu em um maior número de animais. Os aproximadamente 40 casos ocorreram em seis estabelecimentos localizados nos municípios de Castanhal, Santa Maria do Pará, Terra Alta, IgarapéAçu e São Francisco do Pará e Mosqueiro, no período de 19982005. A maioria dos casos se iniciava 20-30 dias após o início do período de maior precipitação (dezembro-janeiro) (Quadro 2).

Quadro 2. Principais dados sobre os eqüinos necropsiados com fotosssensibilização determinada por ingestão de Brachiaria humidicola no Pará

\begin{tabular}{|c|c|c|c|c|c|}
\hline $\begin{array}{l}\text { Procedência/ } \\
\text { Identificação do animal } \\
\text { necropsiado }\end{array}$ & Idade/Sexo & Período & $\begin{array}{l}\text { № de enfermos/ } \\
\text { № total de animais }\end{array}$ & $\begin{array}{l}\text { Evolução e } \\
\text { desfecho }\end{array}$ & Lesões macroscópicas \\
\hline $\begin{array}{l}\text { Castanhal, Faz. Sidergil } \\
\text { FC } 142 \\
\text { (SAP 29630) }\end{array}$ & 2 anos Fêmea & $1999-2000$ & $10 / 30$ & $\begin{array}{l}15 \text { dias } \\
\text { Sacrificado }\end{array}$ & $\begin{array}{l}\text { Carcaça amarelada }+ \\
\text { Fígado esverdeado com desenho de arborização } \\
\text { esbranquiçada }\end{array}$ \\
\hline $\begin{array}{l}\text { Castanhal, Faz. Sidergil } \\
\text { FC 244 } \\
\text { (SAP 29603, 29631) }\end{array}$ & 7 anos Fêmea & $1999-2000$ & $10 / 30$ & $\begin{array}{l}\text { Crônica } \\
\text { Morreu de doen- } \\
\text { ça intercorrente }\end{array}$ & Fígado com desenho esbranquiçado de arborização \\
\hline $\begin{array}{l}\text { Mosqueiro } \\
\text { FC } 251 \\
\text { (SAP 29662) }\end{array}$ & 12 anos Fêmea & 2003 & $1 / 6$ & $\begin{array}{c}\text { Crônica } \\
\text { Sacrificado }\end{array}$ & Fígado moderadamente endurecido \\
\hline $\begin{array}{l}\text { Castanhal, Santa Terezinha } \\
\text { FC } 279 \\
\text { (SAP 30107) }\end{array}$ & 10 anos Fêmea & 2004 & $3 / 10$ & $\begin{array}{l}\text { Mais de um ano } \\
\text { Sacrificado }\end{array}$ & $\begin{array}{l}\text { Carcaça amarelada }+ \\
\text { Fígado moderadamente endurecido }\end{array}$ \\
\hline $\begin{array}{l}\text { Castanhal Cidade } \\
\text { FC } 350 \\
\text { (SAP 30451) }\end{array}$ & Idoso Macho & 2005 & $1 / 1$ & $\begin{array}{c}\text { Crônica } \\
\text { Sacrificado }\end{array}$ & $\begin{array}{l}\text { Carcaça amarelada }++ \\
\text { Fígado com manchas um pouco mais claras }\end{array}$ \\
\hline $\begin{array}{l}\text { São Francisco do Pará } \\
\text { FC } 357\end{array}$ & 2 anos Macho & 2005 & $1 / 5$ & $\begin{array}{l}15 \text { dias } \\
\text { Sacrificado }\end{array}$ & $\begin{array}{l}\text { Carcaça amarelada }+ \\
\text { Fígado com superfície de corte levemente } \\
\text { esverdeada }\end{array}$ \\
\hline (SAP 30490) & & & & & \\
\hline $\begin{array}{l}\text { Castanhal } \\
\text { FC } 358 \\
\text { (SAP } 30491)\end{array}$ & 2 anos Fêmea & 2005 & $\begin{array}{l}9 / 11 \\
5 \text { animais morre- } \\
\text { ram da doença }\end{array}$ & $\begin{array}{l}20 \text { dias } \\
\text { Sacrificado }\end{array}$ & $\begin{array}{l}\text { Carcaça amarelada }+ \\
\text { Fígado com consistência levemente aumentada e } \\
\text { superfície de corte esverdeada }\end{array}$ \\
\hline
\end{tabular}



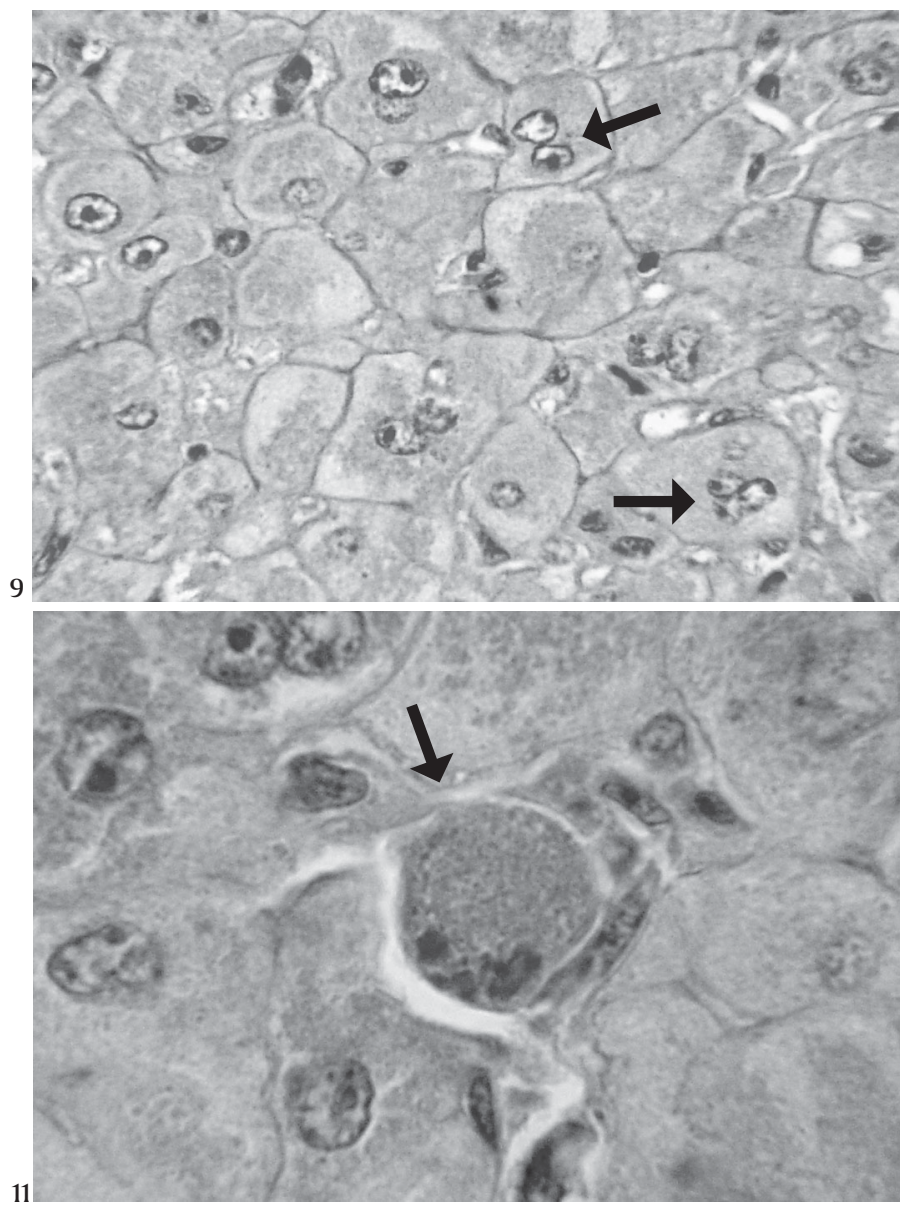

Fig.9. Hepatócitos com aspecto de células vegetais pela marcada tumefação; presença de hepatócitos bi e trinucleados (setas). HE, obj.40.

Fig.11. Necrose coagulativa de hepatócito (seta). HE, obj.100.

A maioria dos animais era da raça Mangalarga Paulista e de mestiços Mangalarga Mineiro com Quarto de Milha, com pelagem, em geral, alazã com extremidades brancas ou, por vezes, tordilha.

\section{Aspectos clínicos e evolução}

$\mathrm{O}$ aspecto clínico da doença foi muito uniforme em todos os casos, variando apenas em intensidade. As lesões eram mais observadas nas partes com pelagem branca, geralmente no chanfro e nas extremidades dos membros (Fig.1). A pele desses locais, de início, tornava-se avermelhada, depois havia exsudação de um líquido citrino que coagulava e formava crostas. Nos casos mais graves, as lesões afetavam também áreas pigmentadas na região da garupa, do pescoço e das narinas (FC 358, SAP 30491). Havia necrose e desprendimento das partes superficiais da pele e separação (fenda) entre a pele e a camada córnea do casco, que se apresentava, junto com a muralha, intensamente vermelha (Fig.2). Parte dos animais evidenciava ulceração na borda da pálpebra e na conjuntiva (Fig.3), por vezes com opacidade de córnea. Nos casos mais graves, os animais emagreciam e a doença terminava
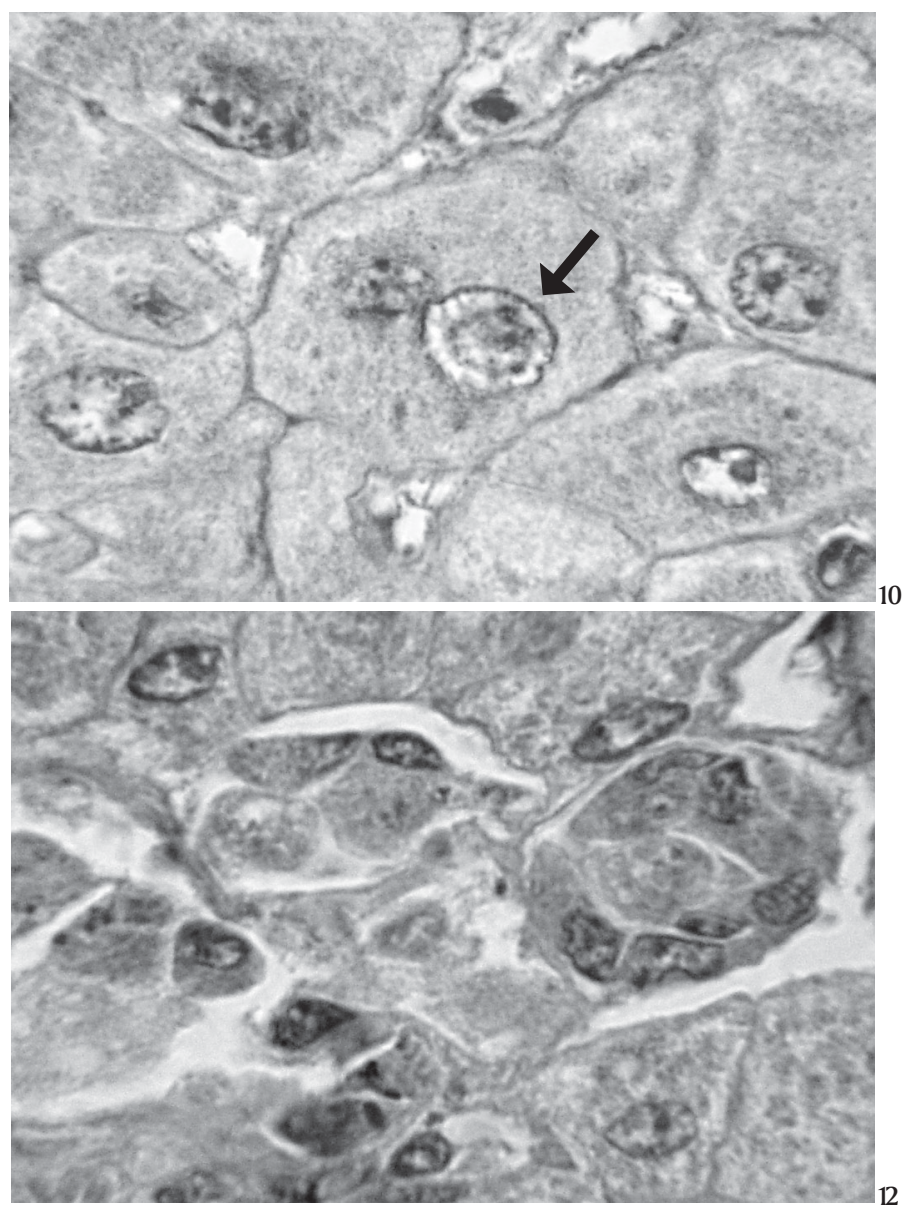

Fig.10. Hepatócitos com aspecto de células vegetais; invaginação citoplasmática no núcleo de um hepatócito (seta). HE, obj.100.

Fig.12. Corte histológico de fígado evidenciando pequena "câmara de digestão" com macrófagos e pigmento marrom fagocitado. HE, obj.100.

com a morte, em seis a oito semanas. Nos casos menos acentuados, com curso clínico de muitos meses, havia um progressivo espessamento da pele nas partes afetadas das extremidades, que se mostravam rugosas, com perdas de pêlos (Fig.4); pelo aparecimento de pequenos ferimentos, a pele tinha aspecto úmido e superfície ulcerada (Fig.5), irregular determinada pela proliferação de tecido de granulação.

Receitava-se medicação à base de corticóides, antibióticos e bacteriostáticos e aplicação de ungüento à base de vitamina $\mathrm{A}$ nas feridas. Também se recomendava que os animais fossem colocados à sombra. Esse tratamento surtia poucos efeitos. Finalmente os animais morriam ou eram descartados.

\section{Achados laboratoriais}

As alterações hematológicas observadas nos eqüinos mantidos em pastagem de Brachiaria humidicola, enfermos ou não, encontram-se no Quadro 1 (Fig. 6, 7 e 8).

\section{Achados de necropsia}

Os principais achados de necropsia constam no Quadro 2. 


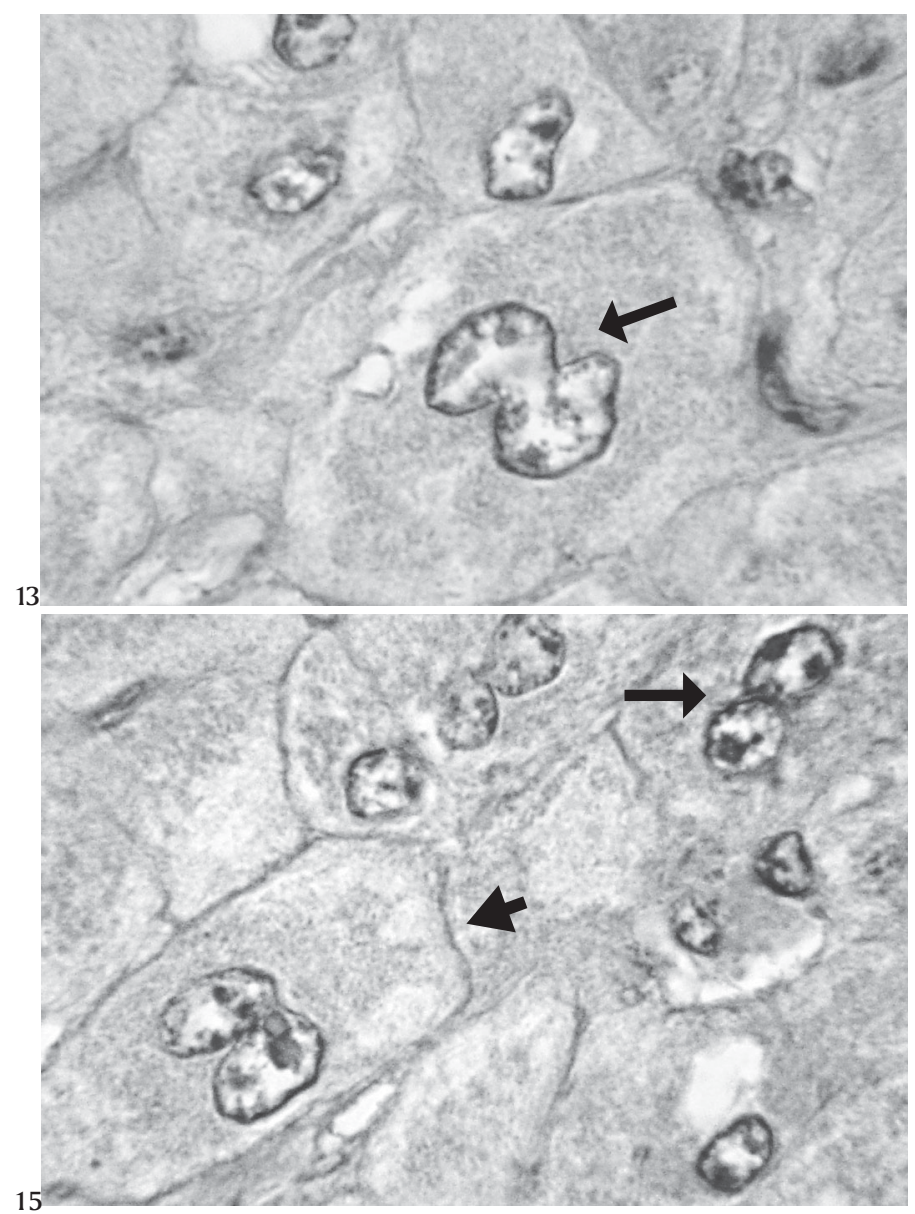

Fig.13. Hepatócito com núcleo bizarro (seta); tumefação celular difusa. HE, obj.100.

Fig.15. Hepatócitos binucleados (seta); hepatócito com núcleo em fase final de divisão; tumefação celular difusa (cabeça de seta). HE, obj. 100 .

\section{Alterações histológicas}

O estudo histológico revelou tumefação celular dos hepatócitos, que adquiriam aspecto de células vegetais (Fig. 9 e 10), com limites celulares bastante nítidos e núcleos vesiculares; esse achado foi constante, variando apenas o grau da intensidade. Em parte dos fígados havia modificações na morfologia nuclear, observando-se megalocitose, numerosos hepatócitos bi ou trinucleados ou com evidente anisocariose (núcleos bizarros ou, por vezes, encarquilhados, com carioteca indentada, irregular, hipercromática e nucléolos evidentes). A marcada reentrância da carioteca observada em alguns hepatócitos sugere divisão celular por amitose (Fig.13-16); havia, adicionalmente, alguns hepatócitos com citoplasma invaginado no núcleo (Fig.10). No figado de um animal (FC 358, SAP 30491) verificaram-se diversos hepatócitos conhecidos como "em vidro fosco" e presença de macrófagos que lembram as "foam cells". Aleatoriamente distribuídos pelo parênquima havia necrose coagulativa (Fig.11) ou lise de hepatócitos isolados ou de pequenos grupos, cujos restos, em outras áreas eram fagocitados por macrófagos, dando origem a formação de pequenas "câmaras de digestão" preenchidas, em adição, por pig-

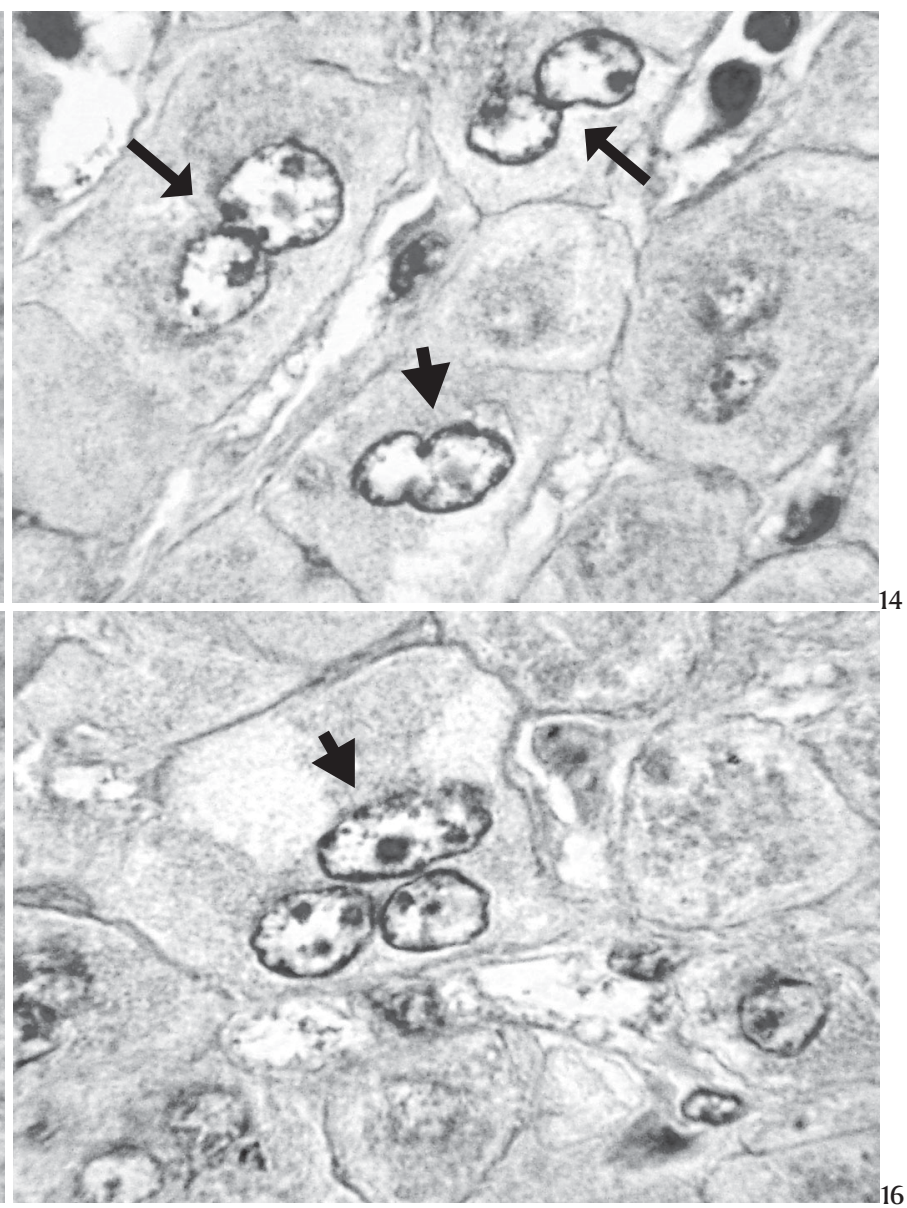

Fig.14. Hepatócitos binucleados (setas); hepatócito com reentrância bipolar na carioteca (cabeça de seta; fase inicial de divisão celular); tumefação celular difusa. HE, obj.100.

Fig.16. Hepatócito trinucleado (cabeça de seta); tumefação celular difusa. HE, obj. 100 .

mento marrom (Fig.12); nesses locais, em um caso, verificaram-se pequenas fendas que sugerem imagem negativa de cristais. Nos espaços-porta observaram-se, por vezes, leve proliferação de fibroblastos com deposição de colágeno, associada a leve infiltração inflamatória mononuclear, a leve proliferação de células epiteliais das vias biliares e numerosos macrófagos que fagocitavam pigmento marrom, homogêneo, com aspecto de lipofuscina ou ceróide; observam-se ainda variáveis graus de retenção biliar (pigmento dentro de hepatócitos e células de Kupffer).

Pormenores sobre a quantificação individual das lesões no fígado dos animais com fotossensibilização constam no Quadro 3.

Na pele de um eqüino que desenvolveu a doença subaguda verificou-se marcada acantose com formação de "rete ridges", acentuada multiplicação de fibroblastos com deposição de colágeno na derme, acompanhada de proliferação de pequenos vasos, incontinência pigmentaria nas áreas de necrose e ulceração da epiderme. Em um dos casos crônicos observaram-se edema e fibrose da derme, dilatação de glândulas sudoríparas e exuberante proliferação vascular. 
Quadro 3. Alterações histológicas no fígado dos animais com fotossensibilização

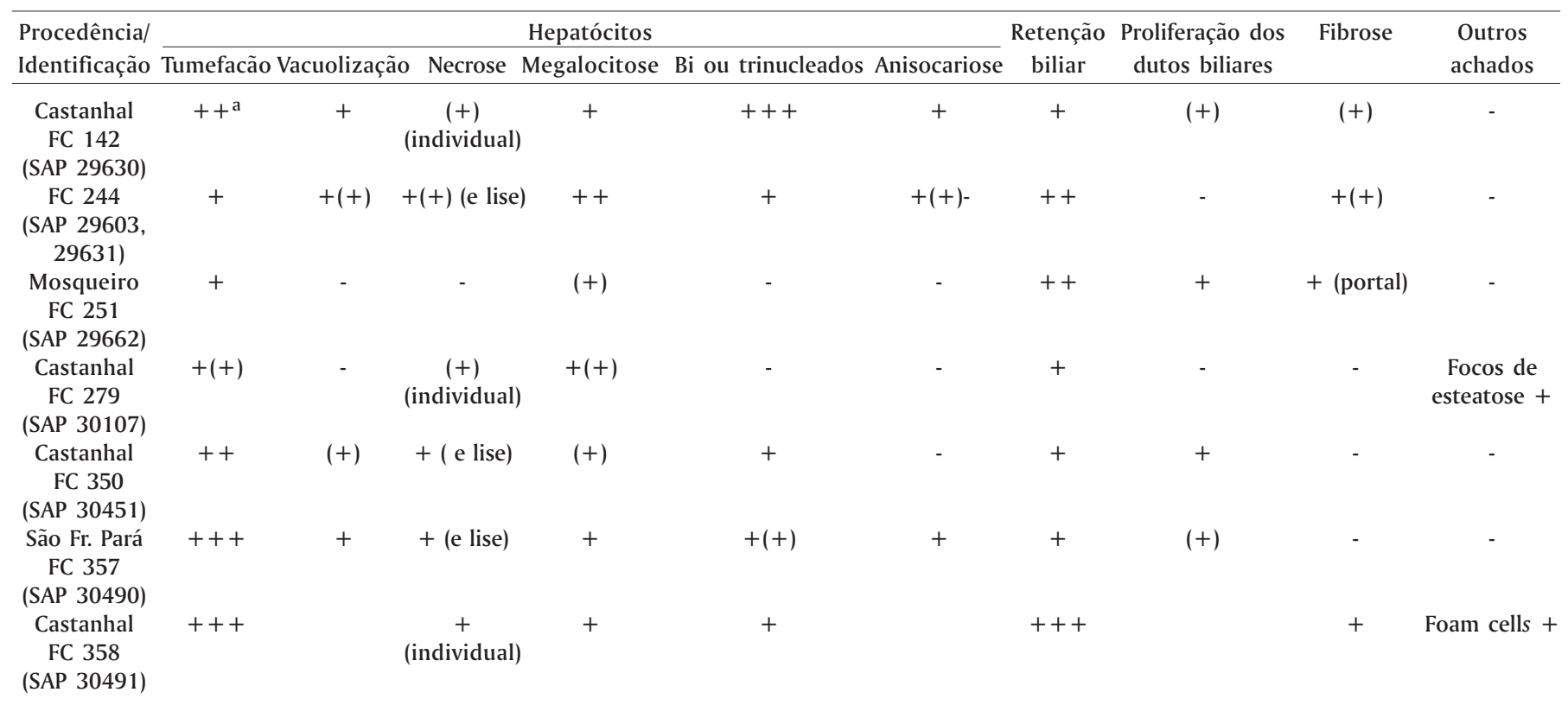

a +++ Lesão acentuada, ++ moderada, + leve, - ausente.

\section{DISCUSSÃO E CONCLUSÕES}

O diagnóstico de fotossensibilização dos eqüinos, no presente estudo, não apresentou maiores dificuldades. As lesões, confinadas, quase sempre, às regiões de pelagem branca, são típicas. A correlação com o agente etiológico, da mesma forma, pode ser feito de forma direta, uma vez que os animais enfermos pastejavam em Brachiaria humidicola, sabidamente capaz de induzir à fotossensibilização em bovinos (Barbosa, dados não-publicados) e búfalos (Tokarnia \& Langenegger 1983). O aparecimento de lesões oculares, como as observadas nesse surto, também tem sido mencionado, por outros autores, em casos de fotossensibilização em eqüinos (Stannard 1994). Em se tratando de equiinos, é difícil estabelecer, até que ponto a coloração amarelada verificada nos tecidos de alguns animais possa ter significado clínico, porém a observação de coloração esverdeada no fígado de alguns animais associada à elevação dos níveis de bilirrubina direta indicam que, realmente, parte dos animais estava ictérica.

As variações nos valores de bilirrubina e da GGT justificam o quadro clínico e demonstram claramente que se trata de fotossensibilização de origem hepatógena

No que se refere aos aspectos anátomo e histopatológicos há algumas considerações a fazer. Em primeiro lugar, deve-se levar em conta que os típicos macrófagos espumosos (foam cells), encontrados no fígado de bovinos que ingerem $B$. decumbens $\mathrm{e}$ B. brizantha (Driemeier et al. 1998, 1999) e de búfalos que pastejam em B. humidicola (Peixoto \& Tokarnia, dados não-publicados) pelo menos até o momento, não foram observados nos casos de intoxicação por B. humidicola em eqüinos; apenas em um caso encontramos aglomerados de macrófagos dentro das chamadas "câmaras de digestão", que lembram "foam cells". Esse é um ponto fundamental que deve ser levado em conta no diagnósti- co de fotossensibilização hepatógena determinada por ingestão de saponinas em eqüinos, uma vez que esse tipo de ocorrência pode estar passando despercebido, se os aspectos clínico-patológicos e epidemiológico não forem considerados.

De resto, as outras lesões histológicas, por enquanto, não devem ser consideradas características, a menos que a imagem negativa de cristais (por sinal de difícil visualização, nesses casos) seja bem evidente. Por outro lado, é possível que, com o avanço dos estudos sobre fotossensibilização em equiinos que pastejam em capins que contêm saponinas, a repetição do quadro microscópico, possa facilitar o diagnóstico. $\mathrm{O}$ significado de hepatócitos bi ou trinucleados, bem como a manifesta anisocariose (Fig.13-16) é mais difícil de determinar, uma vez que não encontramos descrições detalhadas do efeito das saponinas na morfologia do fígado. É possível, porém, que as saponinas esteroidais ajam diretamente sobre o núcleo, estimulando a produção de "nucleoproteínas" e a divisão nuclear, sem entretanto favorecer a divisão dos hepatócitos. É importante estar atento e verificar em futuros casos de fotossensibilização determinados por saponinas em eqüinos, se essas alterações dos hepatócitos são importantes para fechamento do diagnóstico histológico. Fenômeno semelhante (células sinciciais) ocorre na intoxicação por Lantana camara em bovinos (Tokarnia et al. 1984, 2000), na qual, contudo, não ocorre a marcada anisocariose presente nos hepatócitos de eqüinos que ingeriram $B$. humidicola. A patogenia do marcado espessamento da pele nas porções afetadas e, mesmo, a ulceração dessas áreas pode ter relação à dificuldade de drenagem linfática determinada pela fibrose e retração cicatricial da derme e do tecido celular subcutâneo.

Em virtude das típicas lesões cutâneas encontradas em eqüinos, que só ingeriam Brachiaria humidicola, planta sabida- 
mente capaz de produzir lesão hepática e fotossensibilização em bovinos, e em face da acentuada distrofia do fígado dos equiinos afetados, pode-se concluir que os casos de fotossensibilização, motivos deste estudo, foram determinados pela ingestão dessa planta.

Dentro das medidas profiláticas para evitar esse tipo de enfermidade sugere-se ter disponível outro tipo de pastagem, pelo menos na época de início das chuvas na região.

\section{REFERÊNCIAS}

Driemeier D., Barros S.S., Peixoto P.V., Tokarnia C.H., Döbereiner J. \& Brito M.F. 1998. Estudos histológico, histoquímico e ultra-estrutural de fígados e linfonodos de bovinos com presença de macrófagos espumosos ("foam cells"). Pesq. Vet. Bras. 18(1):29-34.

Driemeier D., Döbereiner J., Peixoto P.V. \& Brito M.F. 1999. Relação entre macrófagos espumosos ("foam cells") no fígado de bovinos e ingestão de Brachiaria spp no Brasil. Pesq. Vet. Bras. 19(2):79-83.
Riet-Correa F. 2003. Fotossensibilização primária em eqüinos, p.77-78. In: Riet-Correa F. et al. (ed.) Semi-árido em Foco. Vol. 1. Universidade Federal de Campina Grande, PB, Patos, PB.

Schenk M.A.M., Nunes S.G. \& Silva J.M. 1991. Ocorrência de fotossensibilização em eqüinos mantidos em pastagem de Brachiaria humidicola. Comunicado Técnico, Embrapa-CNPGC, Campo Grande, MS. 3 p.

Stannard A.A. 1994. Fotossensibilização, p.1258-1286. In: Smith B.P. (ed.) Tratado de Medicina Interna de Grandes Animais. Vol. 2. Manole, São Paulo.

Tokarnia C.H. \& Langenegger J. 1983. Relatório de viagem realizada no per[ioodo de 1 a 10.2.1983 para estudar doença de etiologia obscura em búfalos no UEPAE de Manaus. Embrapa, 8p. (Datilografado)

Tokarnia C.H., Döbereiner J., Lazzari A.A. \& Peixoto P.V. 1984. Intoxicação por Lantana spp. (Verbenaceae) em bovinos nos Estados de Mato Grosso e Rio de Janeiro. Pesq. Vet. Bras. 4(4):129-141.

Tokarnia C.H., Döbereiner J. \& Peixoto P.V. 2000. Plantas Tóxicas do Brasil. Editora. Helianthus, Rio de Janeiro. 